\section{Metaphor, Metonymy and Metalepsis: Three Tropes in Contemporary Slovak Documentary}

In 1979, two cognitive scientists, George Lakoff and Mark Johnson, came up with an audacious theory of meaning, according to which

much of our social reality is understood in metaphorical terms, and since our conception of the physical world is partly metaphorical, metaphor plays a very significant role in determining what is real for us. [1]

The traditional theory of metaphor, especially the comparison theory, perceives metaphors exclusively as a matter of language and not a matter of thought or action. According to this theory, metaphor can "only describe pre-existing similarities", but cannot create them. Therefore, in the comparison theory, there "is no such thing as metaphorical thought or action." [2] Lakoff and Johnson refute this conception of metaphor and offer a large number of examples of brand-new metaphors that arose during the period of industrial modernity. They therefore define metaphor as something that "is primarily a matter of thought and action and only derivatively a matter of language." [3] They also explain that " $[\mathrm{t}]$ he primary function of metaphor is to provide a partial understanding of one kind of experience in terms of another kind of experience."

Hence, such conception means "rejecting the possibility of any objective or absolute truth," and also "supplying an alternative account" in which the objective truth is replaced by human experience and understanding.[4] Thanks to this, the theory of conceptual metaphors meets the premises of the theory of literature and its concepts of creative metaphors that do not pre-exist in the world, but come from the author's specific perception of it. However, being strictly subjective, these new metaphors can sometimes reshape the vision of the world we live in.

Yet, unlike literature, and especially poetry, documentary cinema is rarely analysed in terms of tropes and figures. This is probably due to the presumption that documentary can reach and capture reality and show objective, non-manufactured truth. Moreover, the degree of its objectivity often seems to correlate with the absence of tropes or other figures of meaning.

[1] G. Lakoff, M. Johnson, Metaphors We Live By, University of Chicago Press, Chicago 2003, p. 147.

[2] Ibidem, p. 154.
Images

vol. XV/no. 24

Poznań 2014

ISSN 1731-450x

\section{Introduction:}

The tropes we live by 
The presumption of objectivity in documentary cinema was also one of the reasons for some historians of art to reject (documentary) film as œuvre d'art and consider it as a simple mechanical capturing of a visible reality. Eventually weakening during the 1930 os and abandoned by the 1940s, this imperative of objectivity arose again with the success of the "Direct cinema" movement. Technical innovations like light hand-held cameras, sensitive film material that allows shooting interiors without supplementary lighting, and the possibility of recording contact sound set off the hunt for objective reality. The pure observational method of shooting with few or no montage elements seemed to correspond best to the imperative of objectivity,[5] which was, of course, just an illusion, a "trompe l'oeil".[6]

Viewers and sometimes even authors themselves may also forget that every film representation, however observational, is a construct, or - technically speaking - an apparatus-made reduction of a visible reality that was first collected, then once again selected and assembled, and finally edited by the filmmaker. Even the most objective-like documentaries, such as those by the American Frederick Wiseman or the French Raymond Depardon, have to be seen therefore at least as a synecdoche of the world the films refer to: the whole is here replaced by its visible part, and sometimes the cause can even be replaced by its visible consequences.

For Lakoff and Johnson, the term "conceptual metaphor" also includes metonymies and synecdoche. Yet, this is not the case for the theory of literature, with its developed taxonomy of rhetoric and poetic figures and tropes. Synecdoche (and more generally metonymy) is also a trope that transports and changes meaning. At the same time, they operate on the principle of symptom, which is quite often a very specific indicator and an index of some kind of activity.[7] This may be one of the reasons why observational documentaries can pretend to be more objective than subjective, poetic or reflexive documentaries, using metaphors rather than metonymies.

In this article, we examine the way reality is used in film based on such a metaphoric principle, and which employs metonymy as an element supporting metaphorical thinking. At the same time, we will compare this type with other types of film thinking based on metonymy or other rhetoric or poetic figures.

[5] The big defender of "plan-séquence" - the long shoot with no editing - was André Bazin, who also preached the truth or authenticity of filming. See A. Bazin, "Montage interdit", in: Qu'est-ce que le cinéma?, Éditions du Cerf, Paris 1985, pp. 46-61.

[6] The illusoriness of objective and veracious representation - one that is identical to the reality - was pointed at already by Jean Mitry. A confrontation of Basin's understanding of film as a recording of reality with Mitry's critique of this concept is offered in:

F. Casetti, Theories of Cinema, 1945-199o, University of Texas Press, Austin 1999, p. 88.
[7] Metonymy is a trope based on the principle of substituting the part with the whole (e.g. "the entire city has gathered"), the whole with the part ("the price is $12 €$ per head"), cause with consequence ("makes your blood run cold"), or consequence with cause ("desire bulged his pants"), category with type ("drink red"), or type with category ("earn couple of dollars"), content with form ("drink up a glass"), and so on. Thus, metonymic designation constantly adheres to the point of reference, although sometimes only via a small contact area (substituting the whole with the part), or a scant logical correlation. 
Filming is an act of thinking about the world around us. Choosing and selecting what exactly will appear in the film is then a tropological operation. This statement is especially true for authorial documentaries, in which the way a subject is treated is less a matter of format or genre convention than a manifestation of the very principle of how the filmmaker thinks. We therefore propose to study several Slovak documentary films and show differences and similarities between them. The three directors we chose are approximately the same age, all of whom debuted between 2003 and 2008, and all share the experience of having studied at the Academy of Performing Arts under Dušan Hanák - the leading figure in Slovak documentary between 1965 and 1995, and in whose films observational shots or half-stylised, half-reconstructed interviews are deliberately mixed with staged scenes. Such oscillation between reconstruction and staging, i.e. between the observational, or participative, and performative mode of film representation[8] is typical for nearly all filmmakers of this generation. However, despite such common ground, the individual filmmakers differ to a great extent in how they see the world and depict it with figures and tropes. And despite the fact that the synecdochic-metonymic principle generally prevails in documentaries, there are also examples where metaphor enjoys a privileged position.

One such documentary is Cooking History by Peter Kerekes (2009), who is probably the most "metaphorising" documentary filmmaker of his generation. Even the title of his film is a verbal metaphor in which he creates analogy between cooking a meal and writing history. In Slovak, the title Ako sa varia dejiny refers directly to the title of a book by the French historian Paul Veyne, Comment on écrit l'histoire. [9] Used together with the concept of history, the metaphorically significant term "cooking" therefore refers to a construct, a product resulting from a right use of ingredients (information, facts, sources) and a recipe (the right scientific method). Therefore history (or historical text/historical documentary) made this way can be edible, easily digestible, or, on the contrary, a too big bite of a heavy meal. This metaphor is exactly the same as the conceptual metaphor made by Lakoff and Johnson that ideas are actually food.[10]

[8] For modes of representation in documentary films, see chapter 6 and 7 of the second edition of: B. Nichols, Introduction to Documentary, Indiana University Press, Bloomington 2010.

[9] P. Veyne, Comment on écrit l'histoire, Paris 1971. See also P. Veyne, Writing History: Essay on Epistemology, Manchester 1984.

[10] See G. Lakoff, M. Johnson, op. cit., p. 47: "What he said left a bad taste in my mouth. All this paper has in it are raw facts, half-baked ideas, and harmedover theories. There are too many facts here for me
Preferred figures of Slovak documentary filmmakers

\section{Metaphor as an element of structure in Cooking History}


Here, the analogy between food and history in the title is very well chosen. It is connected with the main theme of Kerekes's film: Cooking History shows how the war or armed conflicts of the twentieth and the beginning of the twenty-first century (from WWII to the Chechen War) were perceived by European military cooks.

However, this is not the only metaphor that Kerekes uses.

In these portraits of cooks, Kerekes depicts war as a bloodthirsty monster living on human flesh. War is a Moloch and man is prey, a victim, mere flesh. Meat. Food.

Therefore, war mows people down like wheat or minces them like meat, and Kerekes illustrates this metaphor through recurrent images of cooks or soldiers slaughtering cows or pigs, mincing meat or kneading dough for bread. In this metaphorical field, war is personified, while people themselves are reified, transformed into ingredients. In this metaphor, war consumes, destroys, and mutilates humans.

Peter Kerekes is trying to go further with this metaphor: men become food and war a hungry monster. He tries to create an analogy between a culinary recipe and military orders or commands.

Yet while he is able to illustrate or visualise practically all of the above-mentioned metaphors, he fails with one. Asking the question if the culinary recipe can be compared to an officer's order, one of his protagonists says "the two differ a lot and cannot be compared", seeing a significant difference between the consequences for soldiers who disobey an order and for cooks who just do not follow a recipe: for the first ones, the consequences may be fatal, for the second ones rather banal. Kerekes is a wise filmmaker. He does not insist on this possible metaphorical layer, and concentrates instead on small verbal and visual metaphors and comparisons. For instance, he puts Russian black whole-wheat bread, described as being hard as a stone, in analogy with archive footage of frozen dead bodies from the times of the Leningrad blockade during WWII.

Together with one of his protagonists, he also creates a small landscape on a kitchen table, where a rectangle of bread becomes an airport, a bowl with water the Ladoga Lake, and flour becomes snow. The motif of bread actually shows that in order to render some past events or even ideologies, Peter Kerekes uses metaphor and metonymy or synecdoche at the same time. He asks two of the protagonists a vicious question: Which bread is the best in the world? An old German military baker answers, "German bread is the best". An old Russian female cook says "bread is the same everywhere".

The two protagonists do not only represent their own nations (as a synecdoche of Germany and of the former USSR), their utterances bread becomes a metaphorical designation for ideology: Deutschland über alles vs. communist egalitarianism.

Even though this is not a structuring metaphor, but just a small, partial one, this kind of thinking, in which metaphors are blended with metonymies, is also typical of Kerekes. At the same time, in the bread 
sequences Kerekes also plays with a metonymical idiom that war bread is hard bread. Here, the adjective "hard" denotes the quality of the bread, but it also connotes metonymically the hard job of military cooks.

Another example of blended tropes is one with an Austrian who is being filmed in a cornfield. Behind him, wind turbines are turning, metonymically designating Austria (especially for inhabitants of Bratislava, this metonymy is immediately understood due to the presence of numerous wind turbines along the Slovak-Austrian border), but at the same time it is an allegory of the imminent death threatening soldiers who disobey orders.

The modern wind turbine is then confronted with archival footage where soldiers pass before a classic windmill. This is not only a comparison between now and then, but also an illustration of the saying "the mills of God grind slowly but surely", which is related to the "sin" of the Austrian cook who did not give sugar to a dying little Romanian girl because he wanted to obey his commandant's orders.

Another example where Kerekes mashes up metaphor with synecdoche or metonymy is a portrait of a French cook from the times of the French-Algerian war. The cook is preparing rooster following the famous coq au vin recipe, and a portrait of a former member of parachute troops alternates with it. The naked dead chicken, thanks to its external similarity to a human body, works as a metaphorical and literal illustration of what French propaganda said about what the Algerians were doing to captured French soldiers.

An interesting point here is the chiasm Kerekes creates by the use of montage: the French cook did not want to participate in the war because he was a believing Christian and did not believe the Anti-Algerian propaganda. He did not even want to say what the propaganda was saying. On the contrary, the French parachutist himself did believe it and repeats it voluntarily. Here, Peter Kerekes makes a kind of reconstruction of what the Algerians were supposedly doing: in a voiceover, the paratrooper describes the atrocities, and Kerekes illustrates them through the culinary preparation of the rooster, performed by the pacifistic cook. Here, the dead rooster - a symbol of France - becomes a metaphor for the French soldiers. At the same time, we clearly understand that Kerekes wants us to see the preparation of the meal as an act of violence, too.

This analogy between cooking and violence leads us to the Kerekes's last big thematic metaphor: cooking is fighting. At the end of the film, a Croatian male cook says he "cooks for the Croatian nation" and would never cook for the enemy. On the other hand, two Serbian female cooks say they would not have a problem cooking for Croatians - they are also human and need to eat.

This is also metonymy, based on generalising typical male and typical female behaviour - women are pro-life, and therefore they would feed any humans to allow them to survive, while men are pro-war and perceive even cooking as part of the fight or as their national duty. 
Through the conceptual metaphor of "cooking is fighting" and through the metonymy of "eating with the enemy", which means collaborating, Peter Kerekes deals with the question of loyalty to one's own nation or army, and even with the question of conspiracy as a military strategy: a Jewish baker claims to have poisoned $200 \mathrm{Ger}-$ mans with the bread he made; a Hungarian cook says that in 1956, he fed Hungarian and Soviet soldiers so well they did not feel like fighting with the population anymore; and finally, a Russian cook who cooked for the Soviet Army in occupied Czechoslovakia in 1968 mentions collaborating Czech girls who came to eat and drink with Soviet soldiers.

We can therefore see how Peter Kerekes's thinking in tropes and figures shapes the main theme of his film. Let us now look at the general narrative structure of Cooking History. We have already said its main purpose was to tell the history of war or armed conflicts from the perspective of military cooks. But it is not an oral history; Kerekes actually does not follow the oral historical method. He intervenes into the narrative account of his protagonists; he transforms and deforms it, using what goes well with his concept.

All in all, Peter Kerekes has a formula he follows, and a framework in which he operates and into which he puts particular stories of filmed individuals.

The general narrative structure of Cooking History puts six conflicts (or armed military interventions) together with 14 protagonists and 10 "war" recipes. The narrative account respects chronology (from the 1940s and WWII to the more recent conflicts), with the exception of the Prologue (situated during the Chechen war) and the Epilogue (referring to the sinking of a German military submarine in 1966 - in peace times of the so-called "Cold War"). The structure of the film is episodic. One episode corresponds to one or several stories of one or several military cooks. If there is more than just one story, Kerekes uses parallel montage to jump from one protagonist to another one.

If we look at the structure of the film (table 1), with a little bit of imagination we can see that Cooking History has the structure of a poem, with a prologue and epilogue, with strophes dedicated to individual narrative motifs $(6,7,8$, and finally 11$)$, and with subplots $(4 \mathrm{a}, 4 \mathrm{~b}$, $4 \mathrm{c}$ ), recurrent visual motifs (minced meat, mashed pastry, slaughtered animals) and a leitmotif or intermezzo motif, that is, the transport of the field kitchen by helicopter from place to place, from year to year, which is actually the very principle of metaphor. (Meta-phore literally means transport.)

Moreover, Kerekes works also with other figures of narrative structure, such as ellipses, prolepses (prologue) and analepses (epilogue), and also uses poetic figures such as epiphore - the recurrent image of a written recipe, with a pinch of salt always at the end. 
Table 1. Structure of the narration

\begin{tabular}{|c|c|c|c|}
\hline $\begin{array}{l}\text { Order of } \\
\text { sequence }\end{array}$ & $\begin{array}{l}\text { Chronology/ } \\
\text { order of war } \\
\text { conflict }\end{array}$ & War - point of view/protagonist & Recipe \\
\hline 1. & $\begin{array}{l}0 . \text { Intermezzo } \\
\text { motif }\end{array}$ & $\begin{array}{l}\text { Transport of the field kitchen by helicopter, neutral point of } \\
\text { view, no protagonist, movement to the right/forward }\end{array}$ & no recipe \\
\hline 2. Prologue & 6. & Chechen War - Russian point of view & Shashlik \\
\hline 3. & 0. & Intermezzo & - \\
\hline $4 a$. & 1. & WWII - German and Soviet point of view & Komissbrot \\
\hline $4 \mathrm{~b}$. & 1. & WWII - Soviet, German, Austrian and Jewish point of view & $\begin{array}{l}\text { Empoisoned } \\
\text { bread }\end{array}$ \\
\hline $4 c$. & 1. & WWII - Soviet point of view & Blini \\
\hline 5. & 0. & Intermezzo & - \\
\hline 6. & 2. & Hungarian revolution in 1956 - Hungarian point of view & $\begin{array}{l}\text { Hungarian } \\
\text { sausage }\end{array}$ \\
\hline 7. & 3. & $\begin{array}{l}\text { War in Algeria - pacifist cook's and paratrooper's point of } \\
\text { view }\end{array}$ & Coq au vin \\
\hline 8. & 4. & Occupation of Czechoslovakia in 1968 - Soviet point of view & $\begin{array}{l}\text { Marinated } \\
\text { mushrooms }\end{array}$ \\
\hline 9. & 0. & Intermezzo & - \\
\hline 10. & - & Yugoslavia in peace Tito times - Yugoslavian point of view & - \\
\hline 11. & 5. & War in Yugoslavia - Serb and Croatian point of view & $\begin{array}{l}\text { Baked veal + } \\
\text { Paprikas }\end{array}$ \\
\hline 12. & 0. & Intermezzo - helicopter's return/to the left & - \\
\hline 13. Epilogue & - & Peace times - sunk submarine - German point of view & Schnitzel \\
\hline
\end{tabular}

Cooking History is, of course, primarily a historical documentary. It narrates the past through the subjective stories of military cooks, and makes it universal thanks to several conceptual metaphors. Yet, it is not a traditional historical documentary. Its poetic structure refers to Northrop Frye's thesis in his book New Directions From Old, where Frye states that writing history can be similar to writing poetry. Traditional positivistic historiography shapes the account of what happened out of sources - by induction. The poet guesses or sees the form, the model or the matrix of the world first and then, by employing the method of deduction, s/he fills this form with details and specific images. Some historians may proceed like poets. Some filmmakers may do so, too. Peter Kerekes is one of them.

The metaphorical conception of Cooking History is also close to the conception of Hayden White's Metahistory. White perceives historical writing in terms of tropological pre-figuring. It means the historian accedes to the past with a kind of tropological preconception. $\mathrm{S} /$ he chooses not only the predominant trope but also a genre that is 
determined by the trope. White relates metaphor to romance, metonymy to tragedy, synecdoche to comedy, and irony to satire.

By choosing metaphor as a major trope, Kerekes gives his film a romantic touch, where the military cooks make or at least influence "big history", with sporadic accents of tragedy or comedy, when metaphors are mixed up with metonymies and even reductionist synecdoche.

2. Spatial metaphors and symbols in the film Osadné
Other Slovak filmmakers do not work with metaphor as consistently as Peter Kerekes. Their films are based mostly on presenting, and use analogies only to a minimal degree. Nevertheless, we do find in them several conceptual metaphors, as well as a few other figures.

Director Marko Škop practically does not use verbal metaphors at all. Visual metaphors in his films are also significantly less explicit than in Cooking History. Following his debut Other Worlds (2006), Škop has profiled himself as a director geographer-ethnographer. His Other Worlds portrayed the cultural, ethnic and social diversity of one Slovak region by means of a not always well-chosen synecdochic selection of protagonists. His second full-length documentary Osadné (2009) works with the principle of confronting a small Eastern-Slovak village with the world of a unified Europe and its cultural identity based on diversity.

Despite the seemingly non-metaphoric character of his film, Škop works with the conceptual metaphor of "Osadné goes to Europe", which means Osadné is becoming a European village, taking on European values, and trying to integrate into European projects, showing this transformation is a journey. At the same time, this metaphor has a synecdochic foundation: Osadné, namely its representatives - the mayor and the Orthodox priest - go to Brussels to visit the European Parliament. In a synecdochic way, Europe is represented by Brussels here, which, in its turn, is represented by the European Parliament, and partially also by the Atomium building - a visual symbol of Brussels since 1958.

In Škop's film, space plays an exceptionally important role. The refrain or leitmotif of Osadné is a wide-angle shot of a landscape diagonally divided by a gently sloping road. With regard to this shot, Škop positions Osadné to the left, outside of the frame, somewhere in the mountains, while the road that climbs up towards Osadné servers as an altitude index. Brussels (and synecdochically all of Europe) thus finds itself on the right side, and outside the frame. This way, the shot functions as a cut-out of a larger space - the world of reference - which remains obscured from the viewer to a large extent.[11]

The film's left-right orientation, with its more or less linear story, corresponds to our experience based on literary culture and literature: because we read and write from left to right, our understanding of the
[11] We consider this shot to be of exceptional importance due to the already mentioned apparent close interconnection of direct cinema with reality. Škop is in fact using it to demonstrate that the "world" in a documentary film lies always to a great extent outside of the shot, and what the film does show is inevitably its replacement by a small visible part. 
time continuum is also spatially oriented as flowing from left to right. The beginning is to the left, the end to the right; or, the past to the left, the future to the right. Thus, Škop's space-time orientation of the film is based on the European textual tradition. Thanks to this tradition, the rural environment of Osadné is linked with the old, the past, while Europe stands as a symbol of the new, of the future.

It is no coincidence that at the end of the film, this space-time orientation is inverted. The literary tradition is replaced by a cartographic one, in which east is portrayed on the right, and west on the left. Thus, at the end of the film, the village of Osadné finds itself thrown to the opposite end of the film environment, while Europe suddenly spreads out, almost encircling Osadné from the left. The bipolar space-time model, in which Osadné was an equal partner to, or even encompassing larger narrative space than Brussels, is being replaced by a cartographical proportional model, in which Osadné is reduced to one red dot, above which not even a single European star shines...

Škop re-evaluates the metonymic principle and demonstrates that despite the indexical association of the portrayed reality, cut out from reality as a whole, it necessarily deforms proportions of what it describes. The Orthodox priest and the mayor, a former communist, are metonymising elements of the metaphorical metonymy in "Osadné Goes to Brussels". At the same time, however, the young priest and ageing mayor are not a representative sample of the population of Osadné. Statistically speaking (i.e. from the point of view of a proportional model), they should be joined on their journey by at least a couple of elderly women. Therefore, they only represent the village's political and spiritual life. In the same fashion, Osadné does not take up a larger space than Brussels, even though in the economy of Škop's narration, Osadné has double the space as the million-strong city of Brussels.

In Osadné, we will not find poetic metaphors in every other shot, as is the case with Kerekes; however, what we do find here is a large number of symbols, especially symbols of state or regional affiliation. For example, Škop is filming the first meeting of the priest and the mayor with humourist Fedor Vico in the town of Michalovce, near the Andy Warhol Museum on the patio of a pub under a Šariš beer logo.[12] Consequently, in the following sequence, this advertising logo becomes the metonymic symbol of the entire region. Its pendant is the blue-and-yellow flag of the European Union, which Škop hangs - where else? - in the upper right corner of the pub, while the left corner, as well as other places, is dominated by the Šariš logo. These are joined by other symbols: the Atomium as the symbol of Brussels, and finally a bear as the symbol of Osadné.

However, the symbols Škop is working with cannot be viewed in the Peirceian sense, i.e. as a sign, the meaning of which is based on convention. Škop's symbols are mostly motivated either metonymically

[12] Šariš is the name of the region in Eastern Slova-

kia where the eponymic beer is being brewed. 
(the Atomium), or via conventional metaphors (the EU flag).[13] The only symbol that initially has a completely arbitrary meaning is the wooden bear (it could just as well have been a wolf or an owl), even though metonymically it does refer to the natural environment in which Osadné lies. Vico is the one who introduces the bear's ironic interpretation as a metaphor when he likens Ruthenians to bears, inviting them to activity instead of hibernation.

In Osadné, the protagonists and their projects, which they are going to present in Brussels, can also be viewed through the prism of symbols. The same is true for their stories, which the film captures: the Orthodox priest, a representative of the spiritual life and creator of a future life (during the course of filming, he becomes a father), he wants to build a spiritual centre and revive (or establish) tourism in Osadné; the mayor symbolises the old, those who are departing - he wants to build a funeral home, almost dying himself during the course of the film's shooting. In his own turn, the humourist introduces his project for a tourist Trail Of Europe, which leads to the woods beyond the village, featuring an escalator for the elderly and the disabled. The absurdity of this funny project connecting "new technologies" with traditional values (a return to nature, to one's roots) undermines the euro-optimistic discourse about tradition advancing hand-in-hand with innovation.

At first sight, the structure of Škop's film is linear: the three protagonists set out from Osadné for Brussels, where they meet Slovak and Czech members of the European Parliament (EP), present their projects, invite one of the EP members to visit Osadné, and return home. In the end, they wait for this EP member, and on this occasion plan to unveil a statue of a bear - symbol of the Ruthenians. Of course, the EP member never comes. In a nutshell, this is the story of the film. On the level of discourse, however, it does get somewhat more complicated than that.

After introducing the main protagonists, the Orthodox priest and the mayor of Osadné, who has been in office for 36 years, and following their meeting with the humourist, the latter comes to visit them in the village. In a certain sense, this visit is doubled in the film. First, the humourist talks about it to a TV reporter in a Ruthenian journal, after which we see him travelling in a bus and later crossing a street. In the next shot, we see him once again with the TV reporter. Here, Škop is creating a narrative time-space in which the event and talking about the event coexist side by side, creating multiple time lines which, with regard to chronology, would usually be more distinctly separate from one another. He uses a similar strategy in a sequence

[13] Metaphor can also be seen in the circle of stars that evokes a rim, a connection, a union, but also the golden-blue colouring (the starry sky above us and the moral code within us - meaning a commonwealth of countries based on sharing common values). This is also related to the symbolism of the number 12, which is often repeated in the Bible, while also representing the duodecimal system used for measuring time ( 12 months, $2 \times 12$ hours), thus expressing the shared cultural tradition of all member states. 
devoted to the journey to Brussels, in which the visit of the priest, the mayor and the humourist to the European Parliament is intersected with scenes in which the priest and the mayor, already back home in Osadné, describe to their wives their experience meeting with the EP members. This creates a narrative pseudo-time, in which the account of a protagonist's situation is confronted directly with the situation itself; at times the account of the situation follows the situation, and at other times anticipates it. This is an interesting use of prolepsis and analepsis - figures that project into the present either future events (prolepsis), or past events (analepsis). The situation's relation with a later account of this situation intensifies the situation, introducing its comical elements and enhancing its authenticity.

However, analepsis and prolepsis are an index of a mental operation performed by the author together with the film editor. From a mathematical point of view, this is a very simple operation - a shift, a translation along the timeline. It is this operation that proves the film, however authentic it may seem, is a construct. It does not really matter whether figures are being created on the level of the film's literary preparation, as Peter Kerekes does, or on the level of montage, as Marko Škop does.

The third director, Juraj Lehotský, also offers an interesting example of working with film time-space. If the we as spectators know nothing about the genesis of his film Blind Loves (2008), and if we do not find out from external reviews that it has been predominantly created through the method of reconstruction, we might also perceive it as a time-lapse film. It consists of portraits of three visually impaired couples, and one visually impaired teenager. The story of each couple, as well as of the single teenager, form the film's individual chapters. In addition, four short addenda appear at the end of the film. In the film's first part, an impression is made that the stories are parallel, taking place at the same time. However, in the addenda, we find out that each story has its own time, and these times actually differ significantly. The story that takes place over the longest period of time is that of Elena, who, at the beginning of the film is pregnant and preparing for labour, while at the end of the film she goes to a cinema with her daughter, who at that time is perhaps already six years old. This period of time is confronted with the story of Peter, for whom his wife Iveta starts knitting a pullover at the beginning of the film, and at the end of the film (where Elena already has her six-year-old daughter) gives the pullover to him for Christmas. Such temporal ambivalence can just as well be called anachrony.

From the point of view of meaning, in Blind Loves this anachrony yields quite significant consequences. Since the film is structured into $2 \times 4$ chapters, with the first four being notably longer than the second four, we perceive this latter set of chapters as an epilogue. Because the first part establishes the impression of a consecutive syn-

\section{Anachrony and metalepsis in Blind Loves}


chronous narration, during this epilogue we again tend to perceive it synchronously - as they are all interconnected through the motive of Christmas. However, we also discover a disproportion here (Elena vs. Peter). Consequently, we not only perceive the individual stories as being immersed each in its different time, but in one case, as well; this different time makes us unable to determine the meaning of the epilogue. In the story of the love forming between the blind Roma man Miro and the visually impaired Monika, the main chapter ends with the information of Monika's pregnancy and a shot in which Monika is lying in a hospital bed. The epilogue consequently shows a scene from their household. How much time has passed? Is Monika still pregnant, only it does not show, or should we understand the last shot of the first part as her waiting for an abortion?

The time ambivalence is immanent here to the narrative structure of the film. It is determined by the concept that connects several independent stories into one film chronotope.

However, Lehotský is most interesting for a different figure his apparent diversion from the initial mode of representation. This is because the author inserts a surreal animated sequence into the first story. Apart from that, Blind Loves are characterised by a relatively low frequency of metaphors. To a greater extent, the film features metonymies, which are created by drawing attention to the visual handicaps of the protagonists: the film is dominated by twilight and subdued colours, the evening darkness in a living room, where the married couple actively lives, becomes a metonymy of blindness, as does the absence of curtains or drapes on the windows, the absence of any decorative objects in the homes, and the disharmonic colours in individual parts of their interiors. The only metaphor actually appears on the film poster - a "blind eye" with its retina replaced by a blue planet, as if the blind sight (or imaginations) of the protagonists encompassed the world. It is this blind person's imagination becoming the building block of the last figure that I wish to focus on - it is metalepsis.

According to Pierre Fontanier, metalepsis is a specific example of metonymy, in which direct expression is replaced by an indirect one.[14] The French narratologist and literary theoretician Gérard Genette elaborates that metalepsis is a figure, thanks to which the fundamental level of storytelling (or the film's diegesis) suddenly shifts into a metadiegesis. Thus, the storyteller, or the author, intervenes in the story and draws attention to the fact that he is its maker.[15] There are numerous examples of this both in literature as well as in feature films. Perhaps the most explicit use of metalepsis is offered by Dziga Vertov in his Man With a Movie Camera. However, there are examples of metalepsy also in Peter Kerekes. In his debut 66 Seasons, the film's director of photogra-

[14] P. Fontanier, Des figures du discours, Maire-Nyon, Paris 1977.
[15] G. Genette, Metalepsa, Kalligram, Bratislava 2005. 
phy Martin Kollár suddenly finds himself in front of the camera while reconstructing the past, because one of the protagonists chooses him as the only one from among the men present who resembles her husband, who has been missing for 50 years. In another case, Kerekes himself tells one of his protagonists that film is capable of making miracles, as it can bring back the dead, and consequently via montage inserts here a sequence shot with a man who is, at the time when Kerekes speaks of this miracle, already dead.

With regard to the character of the film world, Lehotsky's animated sequence in Blind Loves can also be understood as metalepsis. Lehotský introduces this sequence with a scene in which the married couple is listening to a radio play about submarine life, after which Peter's wife talks about her imaginings of the submarine world. Peter tries to give this world sound by playing notes on a synthesiser. The sound track accompanying the animated sequence then uses these sounds, with which Peter's imaginings are connected. Lehotský himself then replaces the mental imagining of his protagonists about the submarine world with his own visual imagination of their imagination.

According to Genette, the author's meta-diegetic irruption into the film's diegesis is one of the most personal demonstrations of fiction and fictionalisation. In the case of Lehotskýs film, this effect of metalepsis is evident. In 66 Seasons, the DOP Martin Kollár becomes an actor in a reconstructed sequence shot on an $8 \mathrm{~mm}$ camera. With Vertov, this is predominantly the act of portraying a filmmaker's work on the level of picture, when he shows a filmmaker shooting the same situation seen by the spectator, but also on the level of editing, when he shows a female editor working with film that had previously been exposed by the filmmaker we saw.

However, Gérard Genette does not stop at proclaiming that metalepsis is the place where fiction penetrates into the world of the text or film. For him, each figure is a sign of fiction: this is evident already from the etymology of words, fiction and figure. Both stem from the Latin verb fingere - to create, represent, but also to feign or make up.[16] Thus, fiction influences both metaphor and metonymy.

For documentary filmmakers who praise the observational mode and prefer non-stylised recording or coverage rather than reconstruction or staging, this will undoubtedly come as a provoking claim.

Instead of a conclusion However, in a certain sense, the same stems also from the cognitive theory of meaning by Lakoff and Johnson, according to which metaphorical expressions reflect our understanding of the world, enabling us to understand the unknown and to communicate such understanding to others. 
It is exactly from this point of view that examining figures in documentary films is so important, because it alters our perception of "truthfulness" in documentaries. As a result, truthful might not necessarily appear only that which is "recorded directly", raw and un-manipulated, but equally well also that which is poetic, stylised, created in front of the camera, or subsequently "edited", that which is comprehensible thanks to a topological operation, and what appears to be correct because it corresponds with our idea of the real world, together with the inconspicuous fictions that we live by.

This work was supported by the Slovak Research and Development Agency under contract No. APVV-0797-12 